\title{
Functional specificity of the rainbow trout (Oncorhynchus mykiss) gonadotropin receptors as assayed in a mammalian cell line
}

\author{
Elisabeth Sambroni, Florence Le Gac, Bernard Breton and Jean-Jacques Lareyre \\ Fish Reproduction Research Group, Institut National de la Recherche Agronomique, Station Commune de Recherche en Ichtyophysiologie Biodiversité et \\ Environnement (SCRIBE), Campus de Beaulieu, 35042 Rennes Cedex, France \\ (Correspondence should be addressed to J-J Lareyre; Email: jean-jacques.lareyre@rennes.inra.fr)
}

\begin{abstract}
In vertebrates, gonadotropins (GTHs) (FSH and $\mathrm{LH}$ ) are two circulating pituitary glycoprotein hormones that play a major role in the regulation of gonadal functions, including gonadal cell proliferation/differentiation and steroidogenesis. In mammals, it is well known that their biological effects are mediated by highly specific membrane-bound receptors expressed preferentially on the somatic cells of the gonads. However, in fish, binding and functional studies have shown that cross-reactivity may occur in GTH receptors depending on the species. To understand the molecular mechanisms involved in GTH actions, functional characterization of trout GTH receptors and their gonadal gene expression pattern has been carried out. The present study describes the presence of two distinct GTH receptors in trout showing similarities with those of higher vertebrates but also differences in their
\end{abstract}

structural determinants. In vitro functional studies demonstrate that $\mathrm{rtLH}$ specifically activates its cognate receptor $\left(\mathrm{EC}_{50}=117 \mathrm{ng} / \mathrm{ml}\right)$, whereas purified rainbow trout $\mathrm{FSH}$ (rtFSH) activates FSHR but also LHR at supraphysiological doses $\left(\mathrm{EC}_{50}=38\right.$ vs $598 \mathrm{ng} / \mathrm{ml}$ for FSHR and LHR respectively). The high doses of $\mathrm{rtFSH}$ required to activate LHR put into question the physiological relevance of this interaction. The use of heterologous chinook GTHs confirms the strong preference of each hormone for its cognate receptor. The gonadal expression pattern of the GTH receptor genes suggests that FSH may play an important role in regulating gonadal functions, not only at the early stages but also at the final stages of the male and female reproductive cycles, in addition to the LH pathway.

Journal of Endocrinology (2007) 195, 213-228

\section{Introduction}

The control of the gonadal functions by two plasma heterodimeric glycoproteins (known as gonadotropins (GTHs) and secreted from the gonadotrophs in the anterior pituitary) is a general model in vertebrate reproduction. In fish, two distinct GTH-I and GTH-II have been purified, and the cDNA of the corresponding specific subunits cloned from several species including salmon (Trinh et al. 1986, Suzuki et al. 1988, Sekine et al. 1989, Swanson et al. 1989). Based on their molecular structures and physiological effects, a new nomenclature has emerged and fish GTH-I and GTH-II are now referred to as follicle-stimulating hormone (FSH) and luteinizing hormone $(\mathrm{LH})$ respectively.

In fish, GTHs are differentially secreted in the plasma during the reproductive cycle suggesting that they have specific functions (Prat et al. 1996, Breton et al. 1998, Gomez et al. 1999, Sohn et al. 1999). FSH may play a determinant role in regulating early gametogenesis. In females, the specific role of FSH has been described with respect to the recruitment of oocytes into the secondary (vitellogenic) growth phase as well as in vitellogenin uptake (Tyler et al. 1991, 1997). In males, FSH induced an active spermatogonial proliferation in testicular

explants cultured in vitro (Remacle 1976, Loir 1999) and has recently been shown to be involved in Sertoli cell proliferation (Schulz et al. 2005). In contrast, LH is the major regulating factor of late gametogenesis during oocyte maturation and ovulation (Jalabert 1976). In salmonids, LH alone stimulates production of the maturation-inducing steroid in the granulosa cells $(17,20 \beta$ dihydroxy-4-pregnen-3-one), thus inducing germinal vesicle breakdown (Planas et al. 2000).

In addition, in vitro studies highlighted the ability of both hormones to stimulate steroid production in both ovaries and testis, although their potency differs and is mainly related to gonadal maturation (Swanson et al. 1991, Planas \& Swanson 1995).

As in other vertebrates, once released in the plasma, GTHs bind to membrane-bound receptors expressed on the somatic cells of the gonads. The binding of LH to high-affinity receptors was first demonstrated in the salmonid ovary (Salmon et al. 1984, Breton et al. 1986, Kanamori et al. 1987) and the trout testis (Le Gac et al. 1988). Evidence for two distinct binding activities in the fish ovary originated from other binding studies (Yan et al. 1992, Miwa et al. 1994). In the salmon ovary, ligand-binding assays on gonadal tissue sections followed by autoradiography localized a type I receptor (presumably FSHR) on both thecal 
and granulosa cells, whereas a type II receptor (presumably LHR) was identified on granulosa cells only. In the testis, type I and type II receptors were localized on cells lining the tubules and on interstitial cells respectively (Miwa et al. 1994). Subsequently, the presence of two distinct GTH receptors was confirmed by the molecular cloning of two different cDNA in several fish species: salmon (Oba et al. 1999a,b, Maugars \& Schmitz 2006), catfish (Bogerd et al. 2001, Kumar et al. 2001a,b, Vischer \& Bogerd 2003), and zebrafish (Kwok et al. 2005, So et al. 2005). These membrane receptors belong to the G-protein-coupled receptor (GPCR) superfamily and, in particular, to the subfamily of glycoprotein hormone receptors, characterized by a larger extracellular $\mathrm{N}$-terminal domain, a seven helical transmembrane region, and a short intracellular tail.

Although the overall structure is similar to that described in all other vertebrate species, including reptiles, birds, and mammals, marked differences exist with regard to the hormonal specificity of these receptors toward the fish GTHs. Binding studies with highly purified fish GTHs showed cross-reactivity. In coho salmon, type I receptor (FSHR) was able to bind preferentially to FSH and to a lesser extent to LH (Miwa et al. 1994). In carp, purified GTH receptors bound preferentially to their cognate GTH but a moderate overlapping recognition was described (Basu \& Bhattacharya 2002). Depending on the species, a promiscuous activation of one or the other fish GTH receptors was also reported in functional studies using mammalian cell lines expressing fish receptors. In African catfish, recombinant cfFSH and cfLH activated FSHR with a similar biopotency (Bogerd et al. 2001, Vischer \& Bogerd 2003, Vischer et al. 2003), whereas in amago salmon, only FSH was able to activate FSHR (Oba et al. 1999a). However, hormonal specificity may also depend on the origin of the GTHs. In zebrafish, bovine FSH activated FSHR and LHR, whereas bovine LH specifically activated LHR (Kwok et al. 2005). In contrast, recombinant zebrafish FSH stimulated only FSHR, whereas recombinant LH stimulated both FSHR and LHR (So et al. 2005).

In summary, data from the binding and functional studies do not allow one to draw a general conclusion on the responsiveness of the piscine receptors to GTHs, even in salmonids, and further studies from other fish species or strains are worthwhile.

Besides the functional characterization, our knowledge of the expression pattern of the GTH receptor genes is scarce and limited to a few fish species including catfish (Kumar et al. 2001a,b), zebrafish (Kwok et al. 2005), tilapia (Oba et al. 2001), and salmonids (Campbell et al. 2006, Kusakabe et al. 2006).

In the present study, we report the isolation of two distinct cDNA encoding rainbow trout FSH and LH receptors. Analysis of the amino acid sequences of the fish GTH receptors shows a similar, but not identical, structure to that found in other vertebrates. The expression patterns of the corresponding transcripts have been determined during the male and female reproductive cycles. Distinct temporal expression patterns have been observed in female and male trout. The functional specificity of the trout GTH receptors was studied in transient transfected heterologous cells using purified rainbow trout GTHs (rtFSH and rtLH). Although an $\mathrm{rtFSH}$-induced responsiveness of LHR was observed at supraphysiological doses, we demonstrated that rtLH and rtFSH activate their cognate receptor preferentially.

\section{Materials and Methods}

\section{Animal and tissue collection}

Male and female rainbow trout (Oncorhynchus mykiss) from a fall spawning strain were bred during their first reproductive season at the INRA/PEIMA fish farm (Sizun, France) and held under natural photoperiod and temperature. Monthly sampling was carried out to collect gonads at different gonadal maturation stages. Female gonadal maturation stages were determined as described previously (Jalabert 1976). Trout were anesthetized in 2-phenoxyethanol $(0.03 \% \mathrm{v} / \mathrm{v})$ and ovulation was checked every 3 days. A sample of ovulated females was manually stripped, and kept for 5-15 days after detection of ovulation. Fish were killed by cervical transection and gonads were dissected out of the body cavity under sterile conditions. A piece of the gonads was fixed in Bouin's solution and the rest frozen in liquid nitrogen and stored at $-70{ }^{\circ} \mathrm{C}$, until RNA extraction. For the two full-grown oocyte stages (end of vitellogenesis and maturation), the ovary was deyolked as described previously (Garczynski \& Goetz 1997). The stage of male gonadal maturation was determined by histological analysis after Regaud's hematoxylin/orange G staining (Gabe 1968). Male gonadal stages were determined as described previously (Billard \& Escafffre 1975). Gonadal stage I corresponds to immature male, stage II to active spermatogonial proliferation, stage III to meiosis onset, stage VI to full spermiogenesis, stage VIII to spermiation, and finally stage IX to post-spermiation.

\section{Cloning of GTH receptor cDNA}

To isolate full-length cDNA encoding GTH receptors in trout, known amino acid sequences, corresponding to glycoprotein hormone receptors, were aligned. Two conserved motifs spanning the third extracellular loop (KVSICLP) and the seventh transmembrane $\alpha$-helix (PFLYAI) of these GPCR were chosen to design the forward el2 and reverse el3 degenerated primers. RT-PCR was carried out from testis cDNA and a 352 bp DNA fragment, called the FSHR probe in the present study, was isolated and sequenced. This probe was used to screen, as described previously (Sambroni et al. 2001), a stage III-IV testicular cDNA library, constructed in $\lambda$ ZAP II vector (Stratagene, La Jolla, CA, USA). A single positive clone named FSHR B8 (1337 bp) was obtained with the FSHR probe but was lacking the $5^{\prime}$ extremity of the open reading frame. To complete the $5^{\prime}$ end of the open reading frame, a $5^{\prime}$ RACE-PCR was performed using the rapid amplification of cDNA ends, version 2.0 and the high fidelity elongase (GIBCO BRL Life Technologies). 
Briefly, $1 \mu \mathrm{g}$ total RNA was reverse transcribed with a specific primer Asn172 (Table 1) in order to synthesize the first strand cDNA. After removal of RNA template and purification of the first strand cDNA, an oligo-dC tail was added. The tailed cDNA was amplified with the AAP and Asn136 primers. This allowed us to add $1050 \mathrm{bp}$ upstream from the $5^{\prime}$ end of the FSHR B8 clone. Completion of the open reading frame was carried out by RT-PCR with the RI-1 forward primer design from the $5^{\prime}$ untranslated region of the amago salmon sGTHRI cDNA (AB030012) and Asn2-specific reverse primer.

For LHR cDNA molecular cloning, a partial cDNA fragment was first obtained by RT-PCR from reversetranscribed testicular RNA (stage II) with RII-2 and Asn519 primers (Table 1) designed according to the amago salmon (Oncorhynchus rhodurus) sGTH-R cDNA (AB030005). The PCR product $(440 \mathrm{bp})$ was cloned into the pCR2.1TOPO cloning vector (Invitrogen) and is called the LHR probe in the present study. A full-length cDNA (clone 2b-1) was isolated by screening the rainbow trout testicular cDNA library with the LHR probe as described above.

The nucleotide sequences of the cDNA encoding either the FSHR (2783 bp) or the LHR (2756 bp) have been submitted to GenBank under the accession numbers AF439405 and AF439404 respectively.

\section{$R N A$ extraction and reverse transcription}

Gonadal tissue was homogenized in Trizol reagent (Invitrogen) at a ratio of $1 \mathrm{ml} / 100 \mathrm{mg}$ tissue. Total RNA was extracted according to the manufacturer's instructions and resuspended in nuclease-free water. Two micrograms of total RNA were reverse transcribed in the presence of 200 units of Moloney murine leukemia virus reverse transcriptase (MMLV; Promega) according to the manufacturer's instructions. Reverse transcription of the total RNA was carried out in the presence of either oligo-dT $18(0.5 \mu \mathrm{g} / \mu \mathrm{g}$ total RNA) for the molecular cloning of the $\mathrm{GTH}$ receptor cDNA or in the presence of random hexamers $(0.5 \mu \mathrm{g} / \mu \mathrm{g}$ total RNA) for the quantitative real-time PCR. The reverse transcription reaction was performed in a total volume of $25 \mu \mathrm{l}$, at $37^{\circ} \mathrm{C}$ for $1 \mathrm{~h}$ and $15 \mathrm{~min}$, followed by a $15-\mathrm{min}$ incubation at $70{ }^{\circ} \mathrm{C}$. Control reactions were run without MMLV reverse transcriptase and used as negative controls in the quantitative real-time PCR study.

\section{Quantitative real-time PCR}

Quantitative real-time RT-PCR was performed using an i-Cycler iQ (Bio-Rad). The primers used in the PCRs were 28SFw1/28SRv1, RFSHICF2/RFSHICR2, and RLHICF2/RLHICR2 to amplify the 28S rRNA (reference gene), FSHR, and LHR transcripts respectively (Table 1). At least one of the specific PCR primers was designed on an exon/intron boundary of the FSHR and LHR genes. Reverse transcription products were diluted to 1:40 (or 1:2000 for $28 \mathrm{~S}$ rRNA) and $5 \mu$ were used for each real-time PCR. PCRs were carried out using the qPCR Mastermix Plus for SYBR Green I kit (Eurogentec, Angers, France), according to the manufacturer's instructions. Briefly, a $20 \mu \mathrm{l}$ reaction mix was set up with $5 \mu$ l reverse-transcribed RNA sample, $5 \mu \mathrm{l}$ appropriate primers $(2 \cdot 4 \mu \mathrm{M}$ each), and $10 \mu \mathrm{l}$ $2 \times$ reaction buffer. Thermal cycling was conducted at $50{ }^{\circ} \mathrm{C}$ for $2 \mathrm{~min}, 95^{\circ} \mathrm{C}$ for $10 \mathrm{~min}$, followed by 40 cycles at $95^{\circ} \mathrm{C}$ for $15 \mathrm{~s}$ and $60^{\circ} \mathrm{C}$ for $1 \mathrm{~min}$. Each sample was analyzed in duplicate. A pool of testicular reverse-transcribed RNA originating from stage II testis was serially half diluted and used as standard curve to check the linearity of the amplification and to calculate primer set efficiency. Primers

Table 1 Primers used in PCR experiments

\begin{tabular}{|c|c|}
\hline & Sequences \\
\hline \multicolumn{2}{|l|}{ Primers } \\
\hline $\mathrm{el} 2$ & 5'-AAGGTSAGCATTTGCCTSCC-3' \\
\hline $\mathrm{el} 3$ & $5^{\prime}$-AATMGCCTATAGCAAAGG-3' \\
\hline Asn172 & 5'-GAAGCTCGTGAAGATGAGGATGGC-3' \\
\hline AAP & 5'-GGCCACGCGTCGACTAGTACGGGIIGGGIIGGGIIG-3' \\
\hline Asn136 & 5'-CATGCGCGTTTCAGCACTGGC-3' \\
\hline RI-1 & 5'-GGTGCTGGGACGAGAAAAAGACA-3' \\
\hline Asn2 & 5'-CGGССССТСТGСТССТTTGAA-3' \\
\hline RII-2 & 5'-GAAAAGTTGGATAATTCAATG-3' \\
\hline Asn519 & 5'-ATCCCACTGTTGGATATGSWCARRTA-3' \\
\hline RFSHEXPFw2 & 5'-AAGCTTGAGATGATGAAGATGAAGAAGAAT-3' \\
\hline RFSHOZEXPRV & 5'-AACTGGTTCAAATCAACCAAGATCTAGA-3' \\
\hline RLHEXPFW & 5'-GGATAATTCAATGATGTCGATA-3' \\
\hline RLHEXPRv2 & 5'-TTTCAGGTATAGGGTGCCATT-3' \\
\hline RFSHICF2 & $5^{\prime}$-TCAGTCACCTGACGATCTGCAA- $3^{\prime}$ \\
\hline RFSHICR2 & 5'-TCCTGCAGGTCCAGCAGAAACG-3' \\
\hline RLHICF2 & 5'-СТTСТСААССТСААТGАAАТСТTC-3' \\
\hline RLHICR2 & 5'-GGATATACTCAGATAACGCAGCTT-3' \\
\hline 28SFw1 & 5'-TGTGAACAGCAGTTGAACATGG-3' \\
\hline 28SRv1 & 5'-АTCTGAACCCGАСТСССТTT-3' \\
\hline
\end{tabular}


set efficiencies were $96 \cdot 5 \pm 19 \cdot 2 \%$ for FSHR, $93 \cdot 4 \pm 13 \cdot 2 \%$ for LHR, and $84 \cdot 2 \pm 10 \cdot 5 \%$ for $28 \mathrm{~S}$ rRNA. Correlation coefficients of the standard curves were 0.996 $\pm 0 \cdot 001$, $0.997 \pm 0.001$, and $0.996 \pm 0.02$ for FSHR, LHR, and $28 \mathrm{~S}$ rRNA respectively. No amplification was observed from nonreverse-transcribed sample RNA (from testis at stages I-III, and VIII), indicating the absence of contaminant such as genomic DNA. Specificity of the PCR product was determined from the melting curve analysis $(10 \mathrm{~s}$ holding followed by a $0.5{ }^{\circ} \mathrm{C}$ increase, repeated 80 times, and starting at $\left.55^{\circ} \mathrm{C}\right)$. The mean cycle threshold $\left(C_{\mathrm{T}}\right)$ was calculated for each sample using the iCycler software (Bio-Rad). The relative abundance of target $\mathrm{cDNAs}$ was first normalized with 28S rRNA using the well-established delta $C_{\mathrm{T}}$ method (Livak \& Schmittgen 2001). No significant $(P>0 \cdot 05)$ difference in the reference $28 \mathrm{~S}$ rRNA gene expression was observed between stages of gonadal maturation either in males or in females. Data were analyzed using the nonparametric MannWhitney $U$ test of the Statistica software (Statsoft, France).

\section{Functional characterization of rainbow trout FSHR (rtFSHR) and $L H R$}

The putative open reading frame, including the stop codon of each cDNA, was PCR amplified using RFSHEXPFw2/RFSHOZEXPRv and RLHEXPFw/RLHEXPRv2 primer sets. The resulting PCR products were cloned into the pcDNA 3.1/V5-His-TOPO expression vector (Invitrogen) upstream from the polyadenylation site of the bovine growth hormone gene and downstream the cytomegalovirus (CMV) promoter. The inserts were entirely checked by DNA sequencing on both strands. To test the functionality of FSHR and LHR, we expressed each receptor in COS-7 cells that were cultured in Dulbecco's Modified Eagle's Medium supplemented with 10\% (v/v) newborn calf serum. In total, 500000 cells, seeded onto six-well plates, were cotransfected with either pcDNA 3.1/V5His-FSHR or pcDNA 3.1/V5-His-LHR (500 ng/well) together with $1 \mu \mathrm{g} /$ well of the cAMP-responsive reporter construct pCRE-Luc (Stratagene) and $50 \mathrm{ng} /$ well pCMV $\beta$-galactosidase (Clontech) using $3 \mu \mathrm{l} /$ well of FuGENE6 reagent (Roche Applied Science). Note that DNA quantity was adjusted to $2 \mu \mathrm{g}$ using the pGEM-T vector (Promega). Seven hours after transfection, cells were trypsinized and replated on 24-well plates overnight. Twenty-four hours after transfection, cells were stimulated with purified GTHs for six hours. Incubations were stopped by washing the cells twice with PBS $1 \times$ and adding $100 \mu 1 \times$ cell lysis buffer (Promega Corporation). Cells were incubated for $15 \mathrm{~min}$ under agitation $(100 \mathrm{~g})$ at room temperature, and frozen at $-20^{\circ} \mathrm{C}$ until luciferase activity was measured from $20 \mu$ lysates using the luciferase assay kit (Promega). The $\beta$-galactosidase activity was determined according to the manufacturer's instructions (Promega) from $30 \mu \mathrm{l}$ cell lysates. Each stimulation was performed in triplicate and each experiment repeated at least twice. The hormone concentrations inducing half-maximal stimulation $\left(\mathrm{EC}_{50}\right)$ were calculated using the GraphPad Prism 4 software package (GraphPad Software Inc., San Diego, CA, USA). Rainbow trout and chinook salmon (Oncorhynchus tshawytscha) GTHs were purified using metal ion affinity chromatography and dye-ligand chromatography (Govoroun et al. 1997). The homogeneity and specificity of the GTH preparations were checked by reverse-phase high pressure liquid chromatography (Govoroun et al. 1997) and RIA (Govoroun et al. 1998).

\section{Sequence analysis}

The amino acid alignments of the sequences with other known G-protein-coupled receptors were performed using CLUSTALW and BioEdit shareware. The signal peptide cleavage site was predicted at the SignalP 3.0 Server (http:// www.cbs.dtu.dk/services/SignalP/). The seven membranespanning regions were predicted at the server TMHMM (http://www.cbs.dtu.dk/services/TMHMM-2.0). Prediction of the Ser, Thr, and Tyr phosphorylation sites was carried out at http://www.cbs.dtu.dk/services/NetPhos/. The potential $N$-glycosylation sites were predicted at http://www.cbs.dtu.dk/services/NetNGlyc/.

\section{Statistical analysis}

Data were analyzed using the nonparametric Mann-Whitney $U$ test of the Statistica software based on the ranking method.

\section{Results}

\section{Cloning of transcripts encoding proteins related to the GTH receptors}

To characterize the rainbow trout GTH receptors, the molecular cloning of the corresponding transcripts was undertaken. Two full-length cDNA were isolated from trout testis as described in the Materials and Methods section. Figure 1 shows the deduced amino acid sequence from the open reading frame of each cDNA. The encoded proteins share poor overall homology (42\% identity/56\% homology). A search for conserved functional domains and motifs showed that the putative proteins have a structure similar to that of the GPCR superfamily and, in particular, to the glycoprotein hormone receptors that belong to the $\delta$-subfamily (Fredriksson et al. 2003). Amino acid sequence alignment and phylogenetic analyses with known GPCR showed strong overall homology with the vertebrate GTH receptors (Fig. 2). The distinct cDNA segregated into two different clades, corresponding to each of the GTH receptor types. Therefore, the cDNA were named according to the homologous GTH receptor type. The FSHR cDNA length is $2783 \mathrm{bp}$ and the open reading frame encodes 658 aa corresponding to a $73.7 \mathrm{kDa}$ translated protein. The LHR cDNA is $2756 \mathrm{bp}$ and harbors a 728 aa open reading frame corresponding to an $80.75 \mathrm{kDa}$ translated protein. 


\begin{abstract}
FSHR
MMKMKKIMKM LLCMLGCVCV SQAEVAMVNS GTTFTY̌LCMG NTITHMPTHI PKNTTDLEFK QTHIRVFPRE AFTNLQQLTA 80

IVLTENGMLE SIGAFAFANL PRLTEITITK SKHLVIIHHQ AFIGLPKLSH L ${ }^{*} I C N T G L R V$ LENFSRIHSA ALTFLLDLQD 160

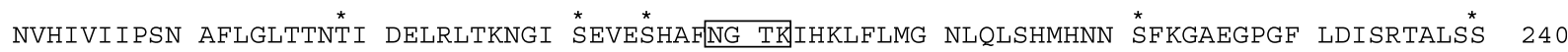

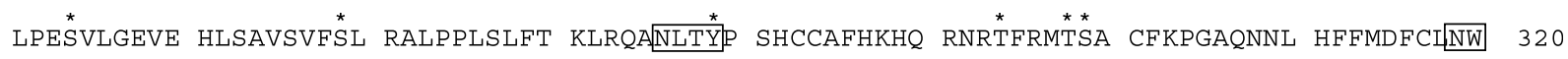

TSVACSPAPD AFNPCEDIMG SAPLRVLIWI TSVLALLGNT IVLLVLLGSR AKMTVPRFLM CHLSFADLCM GVYLVVIATV 400

DVRTRGLYYN HAISWQTGAG CDIAGFFTVF ASELSVFTLT AITLERCHTI THALRLDRKL RLRHACAVMA TGWAFSCLAA 480

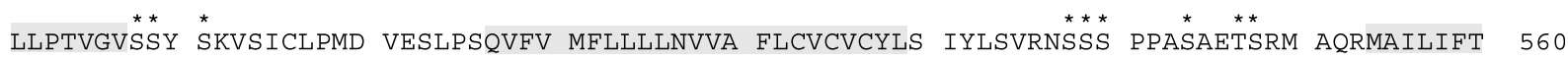

DFLCMAPISF FALSAALKLP LITVSDSKLL LVLLYPINSC ANPFLYGLCT RTFRRDFFLL AARYGLFTTK AQVYRTESFP 640

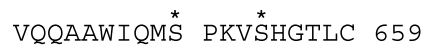

\begin{abstract}
LHR
MMSISLLFLF YPYVLLFFGF GCGYTSSFVC PGICRCSANT $\stackrel{*}{*}$ IRCNNITEKS VPTS̈ERGPRL VLKHLTMSTI ASHTFDGLRR 80 VQHIEIGQSV ALETIETLAF NNLLNLNEIF IKNIRSLVHI ARRTFNNLPK LRY̊L $\stackrel{*}{S} I S N T G$ ITVFPDMTSI HŜLEPWNQNF 160

VLDICDNLYL LSIPVNAFVG MTTEY๋TAMNL FNNGIREIQD $\stackrel{*}{*}$ AFGTKINK LVLKNNRNLR VIHREAFKGA VGPRILDVS̊ 240

TAIETLPSHG LNŚVVELVAR TAYGLKRLPP FRDLGNLQKA HLTYNSHCCA LLTWDTHHRDS PINAAQHNGS RPTYCDDSPPS 320

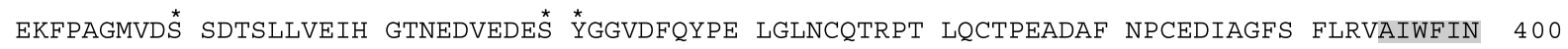

ILAIIGNLTV LLIFFTSRCK LTVPRFLMCH LAFADFCIGV YLLMIAAVDL HTRGHYS̊HA IDWQTGAGCS AAGFLSVFGG 480

ELSVYTLSTI TLERWHTITH ALQLEKRLGL AQAAGIMAGG WLICLGMAML PLVGVSSY $\stackrel{\star}{*}$ VSMCLPMDVK TPLAQAFILL 560

LLLFNVGAFL VVCVCYVLIY LAVRNPQFPS RSADAKIAKR MAVLIFTDLL CMAPISFFAI SAAFKVPLIT VTNSKILLVL 640

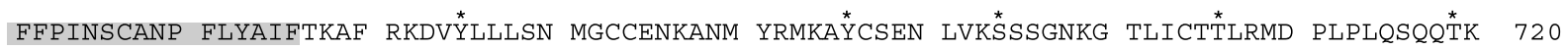

DDGDLGTI 728

Figure 1 Amino acid sequences of rainbow trout FSHR (GenBank accession number AAQ04551) and LHR (GenBank accession number AAQ04550). The predicted signal peptides at the $\mathrm{N}$-terminal are underlined and the putative cleavage sites are indicated with a broken arrow. Boxes and asterisks represent the potential $\mathrm{N}$-glycosylation and phosphorylation sites respectively. The seven transmembrane helices are shown in grey.

The highest similarity for both trout GTH receptors (99\%) is displayed by the Atlantic salmon (Salmo salar) and the amago salmon (O. rhodurus) GTH receptors. Homologies with other FSHR among teleost fish remain rather high ranging from 75 to $80 \%$. The overall homology of trout FSHR with other vertebrate counterparts decreases to around $70 \%$ (human, reptiles, batrachians, birds). Interestingly, LHR appears to be better conserved among fish species (from 83 to $87 \%$ ) with the exception of the tilapia, Oreochromis niloticus (71\%), and the channel catfish, Ictalurus punctatus (69\%). A similar homology with other vertebrates (mammals, birds) is observed which ranges from 69 to $73 \%$.
A structural analysis of the putative rtFSHR and rtLHR amino acid sequences indicates the presence of three main functional regions: extracellular, transmembrane, and intracellular domains. A large extracellular domain that displays similar features to the leucine-rich glycoprotein receptors (LGR) is located at the N-terminal end. This extracellular domain includes a 23 (rtFSHR) to 27 (rtLHR) amino acid region that is highly hydrophobic and encompasses a putative signal peptide, as revealed using the sliding window/matrix scoring method and $-1,-3$ rule for signal peptide prediction. A cluster of nine repeated sequences is observed on each receptor (Fig. 3). These sequences are related to imperfect 


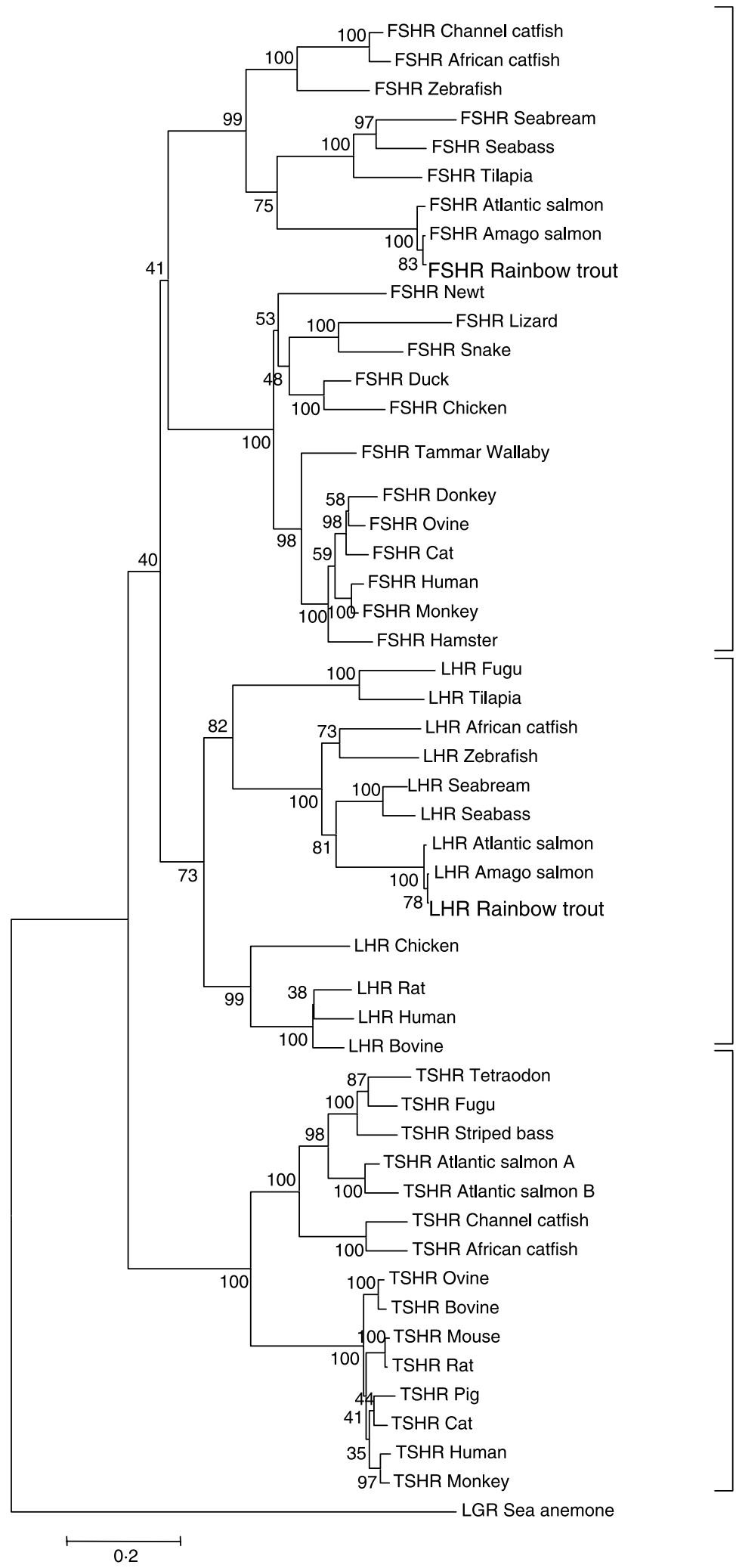

FSHR

LHR

TSHR

www.endocrinology-journals.org 
leucine-rich repeats (LRRs) and most likely form a succession of $\beta$-strands and $\alpha$-helices, organized into a horseshoe-shaped structure. These nine LRRs, conserved in sequence and position between rtFSHR and rtLHR, are similar in length and sequence to the typical LRR (Kajava 1998). Interestingly, the proximal cysteine-rich flanking region that normally links the N-terminal end of the protein to the LRR clusters in mammalian FSHR and LHR, is not found in the rtFSHR sequence. This structural change is observed in salmoniform and perciform FSHR, whereas in zebrafish and catfish, only two of the four cysteine residues liable to form a disulfide bond are present (Fig. 4). The distal cysteine-rich domain that precedes the transmembrane domain is present in both receptors, and is close to the $\mathrm{C}$-terminal cysteine-containing flanking domain 3 (CF3) domain consensus described by Kajava (1998).

The extracellular domain displays five and three potential $\mathrm{N}$-glycosylation sites in rtFSHR and rtLHR respectively (Fig. 1). Only the glycosylation motif (NGT) is conserved in the three glycoprotein hormone receptors out of all species studied so far.

As observed in other vertebrate GTH receptors, the transmembrane domain is the most conserved in terms of sequence and size and is composed of seven hydrophobic regions, forming a tertiary structure of short $\alpha$-helices. Spacer regions that have been involved in extracellular and intracellular loops are also well conserved. Finally, the C-terminal end forms an intracellular domain. The intracellular domain of the rtLHR includes five putative tyrosine or serine/threonine kinase phosphorylation sites. The intracellular domain of the rtFSHR is shorter than that of the rtLHR (52 aa versus $72 \mathrm{aa}$ ) and this feature is also observed in other fish species. In addition to the shorter size, only two putative conserved phosphorylation sites for serine/threonine kinases are found.

\section{Pharmacological characterization of rainbow trout GTH receptors}

The functionality of the trout putative GTH receptors was studied by transient transfection assays in COS-7 cells expressing either one of the receptors. Since it is well established that GTHs induce intracellular cAMP production upon binding to their receptors, an indirect quantification of intracellular cAMP production was carried out using a cAMP-responsive luciferase reporter gene. The high concentration $(800 \mathrm{ng} / \mathrm{ml})$ of purified fish GTHs used in this study did not modulate reporter gene expression in the absence of GTH receptors (Fig. 5A). Transfection of the cells with increasing amounts of the expressing vectors (from 0 to $500 \mathrm{ng} /$ well) showed that, in the absence of a ligand, both trout GTH receptors had no constitutive activity (Fig. 5B and C).

Transactivation data, obtained upon incubation in the presence of GTHs, are reported in Fig. 6 and maximal induction values are indicated in Table 2.

Regarding rtFSHR, a dose-dependent response curve was observed using rtFSH at a concentration of $25-1000 \mathrm{ng} / \mathrm{ml}$ (Fig. 6). A significant $(P<0 \cdot 05)$ maximal $2 \cdot 5$-fold induction (Table 2) of the reporter gene expression was seen at $100 \mathrm{ng} / \mathrm{ml}$. No reporter gene induction was observed in presence of $\mathrm{rtLH}$. Similar results were obtained using chinook GTHs (cFSH and cLH). cFSH was able to activate rtFSHR to a similar level (2.4fold induction) but at a higher dose compared with rtFSH (400 vs $100 \mathrm{ng} / \mathrm{ml}$ ). cFSH potency appeared to be much lower with a calculated effective half-maximum concentration $\left(\mathrm{EC}_{50}\right)$ equal to $200 \mathrm{ng} / \mathrm{ml}$ versus $38 \mathrm{ng} / \mathrm{ml}$ for $\mathrm{rtFSH}$. As observed for $\mathrm{rtLH}$, cLH was not able to induce reporter gene expression regardless of the concentrations used (Fig. 6).

Regarding rtLHR, rtLH induced luciferase reporter gene expression in a dose-dependent manner from 25 to $1000 \mathrm{ng} / \mathrm{ml}$ (Fig. 6). The rtLHR was highly responsive, showing a significant $(P<0 \cdot 05) 8 \cdot 9$-fold induction at $1000 \mathrm{ng} / \mathrm{ml}$, and an $\mathrm{EC}_{50}$ of $117 \mathrm{ng} / \mathrm{ml}$. Interestingly, high doses of rtFSH (1000-1600 ng/ $\mathrm{ml}$, data not shown) were also able to induce a significant $(P<0 \cdot 05)$ and reproducible twofold induction of the reporter gene expression. However, the biopotency of $\mathrm{rtFSH}$ in activating rtLHR was 16-fold lower compared with that calculated for $\mathrm{rtFSHR}\left(\mathrm{EC}_{50}=598\right.$ vs $38 \mathrm{ng} / \mathrm{ml}$ for $\mathrm{rtLHR}$ and rtFSHR respectively). The heterologous chinook GTHs were also tested. cLH induction resulted in a similar dosedependent responsiveness to that obtained in the presence of $\mathrm{rtLH}$. The biopotency of cLH was similar to that of $\mathrm{rtLH}$ with an

\footnotetext{
Figure 2 Phylogenetic analysis of rainbow trout gonadotropin receptors. Amino acid sequences of known or predicted glycoprotein hormone receptors were first aligned using CLUSTALW, and the resulting alignment was analyzed using the MEGA software. The analysis was carried out on full-length protein sequences using two different algorithms (minimum evolution and neighbour-joining methods). Similar trees were obtained but only the analysis performed by the neighbour-joining method is represented. The numbers beside the branches indicate bootstrap values from 100 replicates. The scale bar corresponds to estimated evolutionary distance units (MYA). The outgroup used to build the tree is the sea anemone leucine-rich repeat containing G-protein-coupled receptor (Z28332). TSHR sequence accession numbers are AY533543 (channel catfish), AY129556 (African catfish), AF239761 (striped bass), AB030954 (TSHRA, amago salmon), AB030955 (TSHRB, amago salmon), fugu (unpublished results), tetraodon (unpublished results), NM_012888 (rat), BC092523 (mouse), NM_001009410 (sheep), NM_174206 (bovine), AF218264 (cat), NM_214297 (pig), AY169400 (monkey), and AY429111 (human). LHR sequences are AF324540 (African catfish), AY424302 (zebrafish), fugu (unpublished results), AY642114 (sea bass), AF439404 (rainbow trout), AB030005 (amago salmon), AB041763 (tilapia), AJ579790 (Atlantic salmon), AY587261 (sea bream), NM_204936 (chicken), NM_012978 (Rat), U20504 (bovine), and NM_000233 (human). FSHR sequences are AY587262 (sea bream), AJ567667 (Atlantic salmon), AF285182 (channel catfish), AB030012 (amago salmon), AF439405 (rainbow trout), AY278107 (zebrafish), AY642113 (sea bass), AB041762 (tilapia), AJ012647 (African catfish), AY189696 (snake), AB005587 (newt), AJ292553 (lizard), NM_205079 (chicken), AY099289 (duck), AY082002 (tammar wallaby), AY509907 (hamster), AY521181 (cat), U73659 (donkey), NM_001009289 (sheep), NM_214386 (pig), XM_001114171 (monkey), and M65085 (human). Note that rainbow trout cDNA encoding glycoprotein hormone receptors segregate into two distinct clades, corresponding to the FSHR and LHR genes.
} 


\begin{tabular}{|c|c|c|c|c|}
\hline LHR & RGPRLVLKHLTMST-IASHTFDGLR & $56-$ & & 79 \\
\hline FSHR & T-TDLEFKQTHIRV-FPREAFTNLQ & 54 & - & 76 \\
\hline LHR & RVQHIEIGQSVALETIETLAFNNLL & 80 & - & 104 \\
\hline FSHR & QLTAIVLTENGMLESIGAFAFANLP & 77 & - & 101 \\
\hline LHR & NLNEIFIKNIRSLVHIARRTFNNLP & 105 & - & 129 \\
\hline FSHR & RLTEITITKSKHLVIIHHQAFIGLP & 102 & - & 126 \\
\hline LHR & KLRYLSIS-NTGITVFPDMTSIHSLEPWN & 130 & - & 157 \\
\hline FSHR & KLSHLTIC-NTGLRVLPNFSRIHSAA & 127 & - & 151 \\
\hline LHR & QNFVLDICDNLYLLSIPVNAFVGMTT & 158 & - & 183 \\
\hline FSHR & LTFLLDLQDNVHIVIIPS - AFLGLTTN & 152 & - & 178 \\
\hline LHR & EYTAMNLFNNG -IREIQDYAFNGT & 184 & - & 206 \\
\hline FSHR & TIDELRLTKNG - ISEVESHAFNGT & 179 & - & 201 \\
\hline LHR & KINKLVLKNNRNLRVIHREAFKGAV & 207 & - & 231 \\
\hline FSHR & KIHKLFLMGNLQLSHMHNNSFKGAE & 202 & - & 226 \\
\hline LHR & GPRILDVSSTA-IETLP - - SHGLN & 232 & - & 252 \\
\hline FSH & GPGFLDISRTA-LSSLPE-SVLGE & 227 & - & 248 \\
\hline LHR & SVVELVARTAYGLKRLPPFRDLG & 253 & - & 275 \\
\hline FSHR & -VEHLSAVSVFSLRALPPLSLFTK & 249 & - & 271 \\
\hline
\end{tabular}

Schematic representation of the extracellular domains
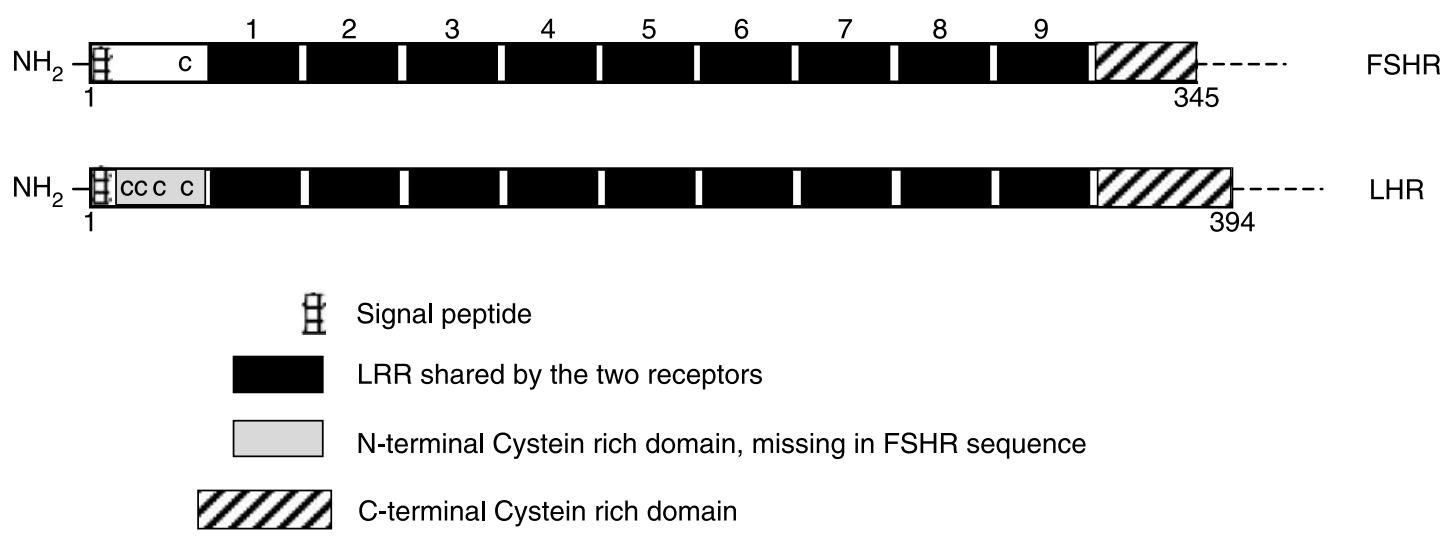

Figure 3 The nine repeat sequences found in the extracellular domains of rainbow trout FSHR and LHR are related to imperfect leucine-rich repeats (LRRs). Spaces have been added to improve the alignment. The consensus sequence of LRR (Kajava et al. 1995) is indicated below the alignments. A schematic of the extracellular domains is shown at the bottom which indicates the position of different structural motifs: signal peptide, the LHR N-terminal cysteine-rich flanking region containing four cysteine residues (c), the cluster of imperfect LRR numbered 1-9, and the C-terminal cysteine-rich flanking region. The amino acids delineating the ectodomain are indicated. Note the absence of the $\mathrm{N}$-terminal cysteine-rich flanking region on rtFSHR. 


FSHR trout
FSHR salmo salar
FSHR amago
FSHR seabass
FSHR tilapia
FSHR zebra
FHSR c catfish
FSHR af catfish
FSHR rat
FSHR human
FSHR bovin
FSHR chicken
FSHR duck

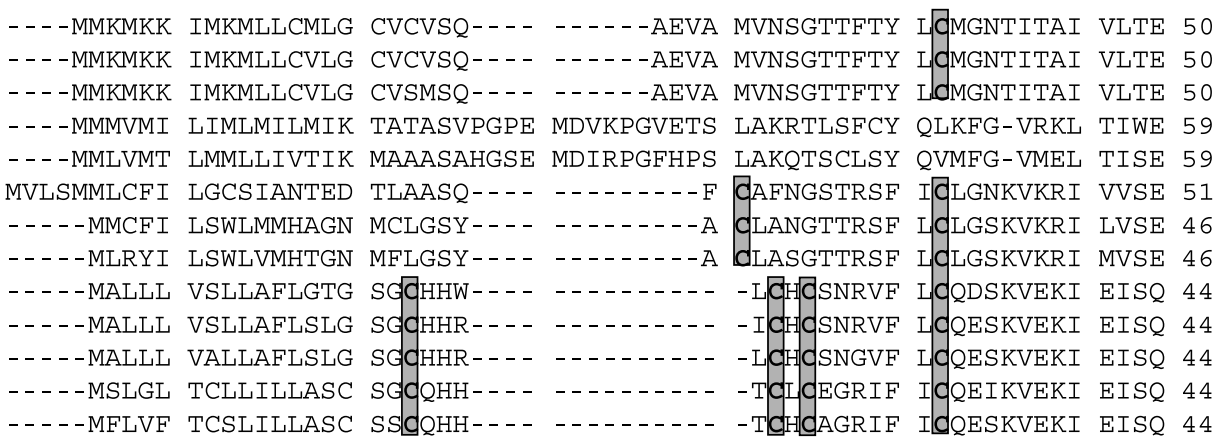

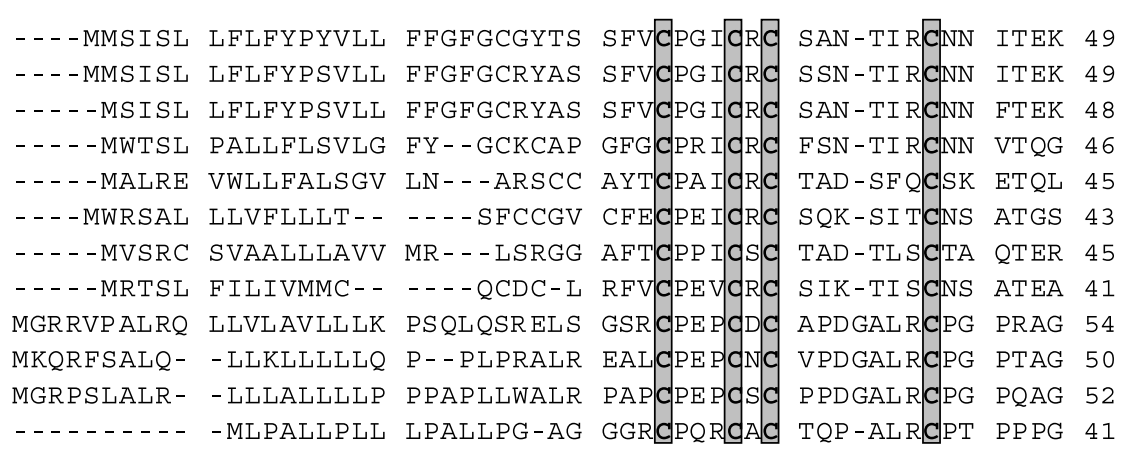

Figure 4 Alignment of the rtFSHR and rtLHR N-terminal cysteine-rich flanking regions with those of other piscine and mammalian species. Conserved cysteine residues are shown bold in grey boxes. c catfish, channel catfish; af catfish, African catfish.

$\mathrm{EC}_{50}$ equal to $98 \mathrm{vs} 117 \mathrm{ng} / \mathrm{ml}$ for $\mathrm{rtLH}$ (Table 2), with an 11 -fold maximal induction obtained at $400 \mathrm{ng} / \mathrm{ml}$. Unexpectedly, contrary to rtFSH, cFSH had no significant effect on rtLHR transactivation at the tested doses.

In summary, functional data indicate that, in our assay system, rtLHR and rtFSHR showed a marked functional specificity to their cognate ligand.

Expression pattern of the trout GTH receptor genes in the gonads

To provide new insight into trout GTH receptor function, the expression pattern of their genes was studied over the annual reproductive cycle in female and male trout using quantitative real-time PCR. In females, rtFSHR and rtLHR transcripts were present in all stages studied (Fig. 7); however, different expression patterns were found for the two messengers prior to spawning (Fig. 7B). The relative abundance of rtLHR transcript significantly increased during the ovulation period (fivefold, $P<0 \cdot 05)$. Unexpectedly, the relative abundance of rtFSHR peaked significantly $(P<0 \cdot 05)$ earlier, just before spawning at final oocyte maturation and ovulation (sixfold compared with the end of vitellogenesis).
We previously showed an inverse evolution of GTH plasma levels after ovulation, dependent on whether the eggs were retained in the abdominal cavity (Breton et al. 1998). FSH secretion significantly increased after ovulation in fish without eggs, whereas in fish that retained eggs, FSH secretion remained constant. The LH profile was exactly the opposite, being significantly higher in fish with eggs compared with those that were stripped. In order to determine whether a modification in the plasma hormonal balance, induced after ovulation by egg removal, correlates with changes in GTH receptor gene expression, we examined the relative abundance of ovarian rtFSHR and rtLHR transcripts in ovulated females with or without eggs retained in the abdominal cavity after ovulation (Fig. 7C). The relative abundance of rtFSHR transcripts significantly decreased after ovulation (fivefold decrease, $P<0 \cdot 05)$. This decrease seemed to be slightly delayed in females that retained eggs in the abdominal cavity, but a significant difference between the two groups (twofold, $P<0 \cdot 05$ ) was only detected 10 days after ovulation. On the contrary, rtLHR transcript did not change significantly for up to 15 days after ovulation, and no significant difference was observed in females with or without eggs. 

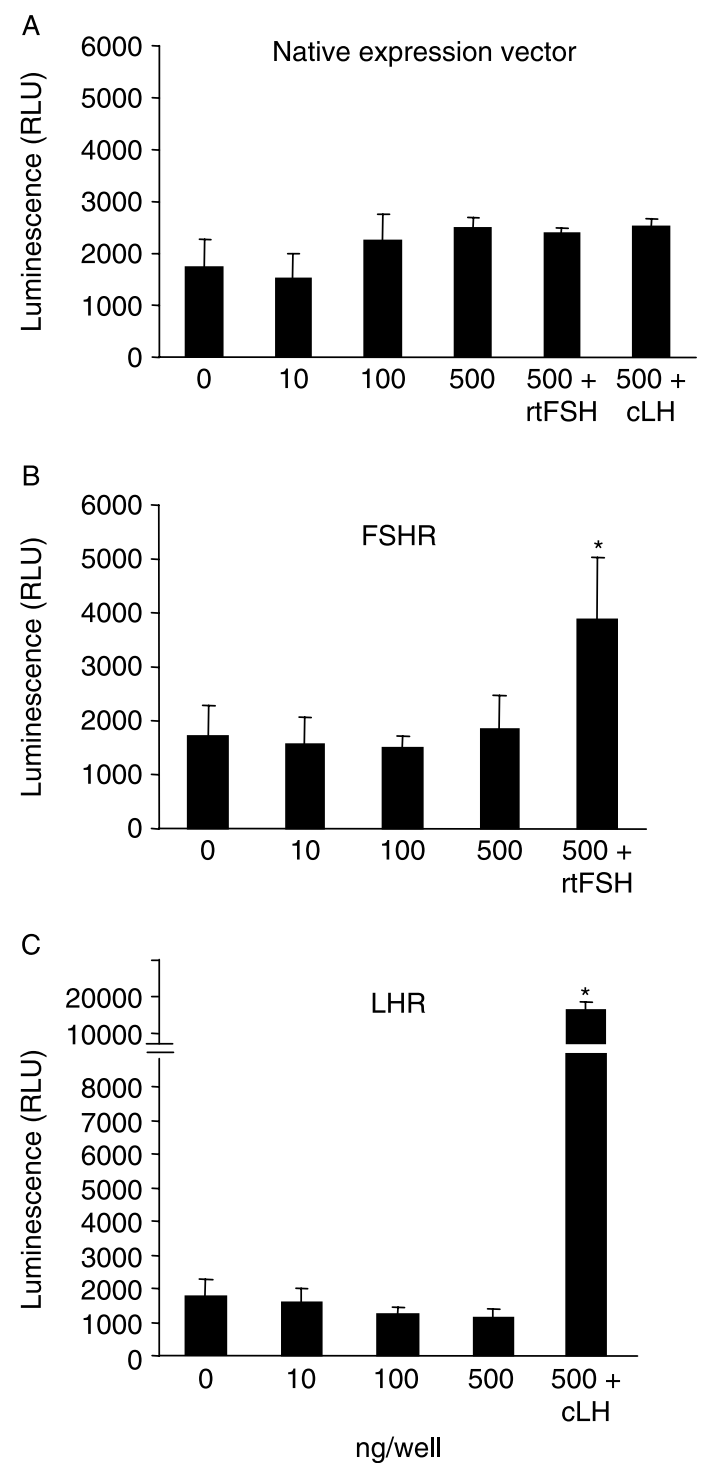

Figure 5 Analysis of the basal activity of rainbow trout gonadotropin receptors. COS-7 cells were cotransfected with increasing amounts (from 0 to $500 \mathrm{ng} /$ well) of native (A) or trout gonadotropin receptor ( $\mathrm{B}$ and $\mathrm{C}$ ) expression vectors, together with the cAMP-responsive reporter construct pCRE-Luc. Cells were incubated in the absence of gonadotropins or were stimulated for $6 \mathrm{~h}$ in the presence of $800 \mathrm{ng} / \mathrm{ml}$ $\mathrm{FSH}(+\mathrm{rtFSH})$ or $\mathrm{LH}(+\mathrm{cLH})$ as a positive control. cAMP production was indirectly quantified by measuring the luciferase activity from the reporter vector. Each data point represents the mean \pm s.D. of triplicates of a representative experiment.

In males, rtFSHR and rtLHR transcripts were also present in all the studied stages and their expression followed a similar pattern (Fig. 8). In immature fish and during the gonial proliferation period (stages I and II), the relative abundance of both transcripts did not change significantly. Starting from meiosis onset to full spermiogenesis, there was a progressive and significant $(P<0 \cdot 05)$ decrease in rtFSHR and rtLHR transcripts (8- and 12-fold decrease respectively). However, normalization of the data corrected for the reference gene, the gonadosomatic index and RNA extraction yields indicate no significant change in the rtFSHR and rtLHR messenger levels during spermatogenesis. Interestingly, independent of the normalization procedure used, both transcripts reached their maximum expression at spermiation (four- to fivefold increase for $\mathrm{rtFSHR}$ and $\mathrm{rtLHR}$ respectively compared with the immature gonadal stage I). In post-spawning males (stage IX), rtFSHR levels returned to nearly immature levels, whereas rtLHR messengers continued to be expressed at a level five times greater than that in immature fish. Normalizing the data for the gonadosomatic index and RNA extraction yields showed that the accumulation of the GTH receptor transcripts remained high in post-spawning/regressing male compared with immature fish.

\section{Discussion}

\section{Structure of trout GTH receptors}

In the present study, we identified two distinct cDNA encoding rainbow trout GTH receptors based on the analyses of their amino acid primary sequences and on in vitro functional studies with homologous and heterologous purified GTHs. The presence of high-affinity receptors for LH was previously demonstrated in male and female trout from in vitro binding assays to membrane preparations or purified GTH receptors (Quesnel \& Breton 1993). Since no binding study has been carried out with purified trout FSH, clear evidence for a second distinct GTH receptor type in trout relied mainly on in vitro biological studies where purified FSH was shown to act on specific gonadal functions. Loir $(1994,1999)$ showed that purified $\mathrm{rtFSH}$, but not $\mathrm{rtLH}$, was a potent mediator of trout spermatogonia proliferative activity in vitro.

The presence of two genes encoding distinct GTH receptors in trout is in agreement with previous reports on other fish species, including amago salmon (Oba et al. 1999a,b), Atlantic salmon (Maugars \& Schmitz 2006), African catfish (Bogerd et al. 2001, Vischer \& Bogerd 2003), channel catfish (Kumar et al. 2001a,b), and zebrafish (Laan et al. 2002, Kwok et al. 2005). Analysis of the overall architecture indicates that the two trout receptors should be considered as new members of the GPCR superfamily and, in particular, to the glycoprotein hormone receptor (GpR) subfamily. Members of the GpR subfamily are characterized by a large N-terminal extracellular domain (ectodomain), a conserved seven $\boldsymbol{\alpha}$-helix transmembrane region, and a short C-terminal intracellular tail (Fredriksson et al. 2003). Each trout GTH receptor is highly similar to that of the few other fish counterparts identified so far, suggesting that two distinct GTH receptors are well conserved among euteleosts. Moreover, with the exception of the pCRR structural domain located at the N-terminal end of the mammalian FSHR, fish GTH receptors share similar structural motifs with their 

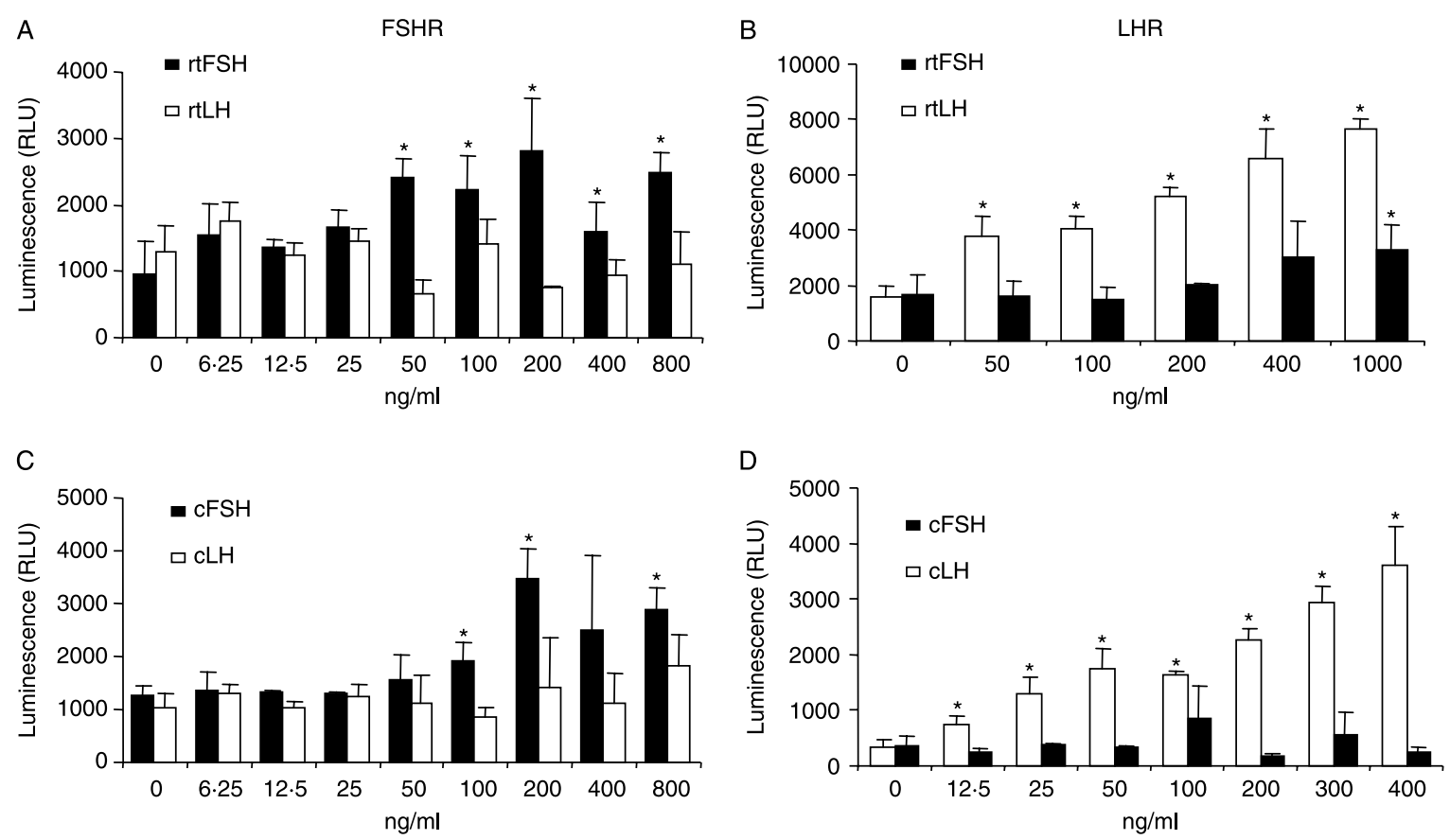

Figure 6 Transient expression and hormone responsiveness of rainbow trout FSHR and LHR. COS-7 cells were cotransfected with trout gonadotropin receptor expression vectors together with the cAMP-responsive reporter construct pCRE-Luc. Cells were incubated for $6 \mathrm{~h}$ with increasing doses of either rainbow trout (A and $B$ ) or chinook salmon gonadotropins $(C$ and $D)$. Hormone-induced cAMP production was indirectly quantified by measuring the luciferase activity from the reporter vector. Each data point represents the mean \pm s.D. of triplicates of a representative experiment.

reptilian, avian, and mammalian counterparts, indicating that they have been well conserved in all vertebrates during evolution. This assumption is also supported by the molecular phylogenetic analysis of the known vertebrate glycoprotein receptors, indicating that the two receptor types have emerged from a common ancestral gene.

\section{In vitro hormonal specificity of the trout GTH receptors}

To characterize their hormonal specificity at a functional level, trout GTH receptors were overexpressed in COS-7 cells together with a cAMP-responsive luciferase reporter gene and stimulated with an increasing amount of homologous or heterologous purified GTHs. As expected, the endogenous ligands were more potent in stimulating their cognate receptor, but the calculated $\mathrm{EC}_{50}$ required to transactivate $\mathrm{rtFSHR}$ (rtFSH: $38 \mathrm{ng} / \mathrm{ml}$ ) and rtLHR (rtLH: $117 \mathrm{ng} / \mathrm{ml}$ ) appeared to be higher than trout plasma GTH levels, which range from $2 \mathrm{ng} / \mathrm{ml}$ in juvenile to $15 \mathrm{ng} / \mathrm{ml}$ in sexually mature animals (Gomez et al. 1999). It is not known whether the apparent high $\mathrm{EC}_{50}$, required to activate fish GTH receptors in vitro, is due to reduced biological hormone activities resulting from purification/conservation procedures.

Although $\mathrm{rtFSH}$ preferentially activates its own receptor, the rtFSHR maximal response to rtFSH (2.5-fold) was much lower than that of rtLH on rtLHR (about 9-fold). However, such a

Table 2 Effective half-maximum concentration $\left(\mathrm{EC}_{50}\right)$ and maximum induction calculated for each rainbow trout gonadotropin receptor. The maximum induction values are relative to the basal expression of the reporter gene measured in the absence of hormone. Data are the mean \pm s.D. of three replicates of a representative experiment

\begin{tabular}{|c|c|c|c|c|}
\hline & \multicolumn{2}{|r|}{ FSHR } & \multicolumn{2}{|c|}{ LHR } \\
\hline & $\mathrm{EC}_{50} \mathrm{ng} / \mathrm{ml}$ & Maximal induction & $\mathrm{EC}_{50} \mathrm{ng} / \mathrm{ml}$ & Maximal induction \\
\hline \multicolumn{5}{|c|}{ Hormones } \\
\hline $\begin{array}{l}\text { rtFSH } \\
\text { cFSH }\end{array}$ & $\begin{array}{l}38 \\
200\end{array}$ & $\begin{array}{l}2 \cdot 5 \pm 0 \cdot 1 * \\
2 \cdot 4 \pm 0 \cdot 3 *\end{array}$ & $\begin{array}{l}598 \\
\text { na }\end{array}$ & $\begin{array}{l}2 \cdot 9 \pm 0 \cdot 1^{*} \\
1 \cdot 0 \pm 0 \cdot 2\end{array}$ \\
\hline rtLH & na & $1 \cdot 2 \pm 0 \cdot 2$ & 117 & $8 \cdot 9 \pm 0.9 *$ \\
\hline cLH & na & $1 \cdot 8 \pm 0 \cdot 6$ & 98 & $11 \cdot 0 \pm 2 \cdot 1^{*}$ \\
\hline
\end{tabular}

*Significant induction $P<0 \cdot 05$; na, not applicable. 

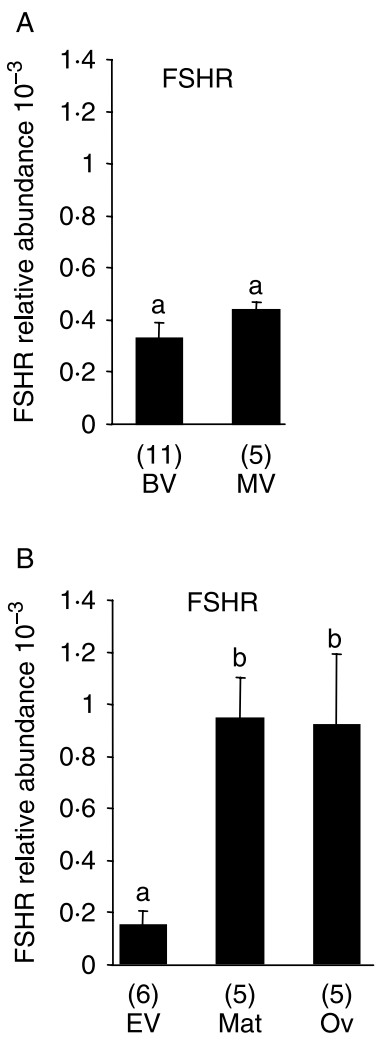
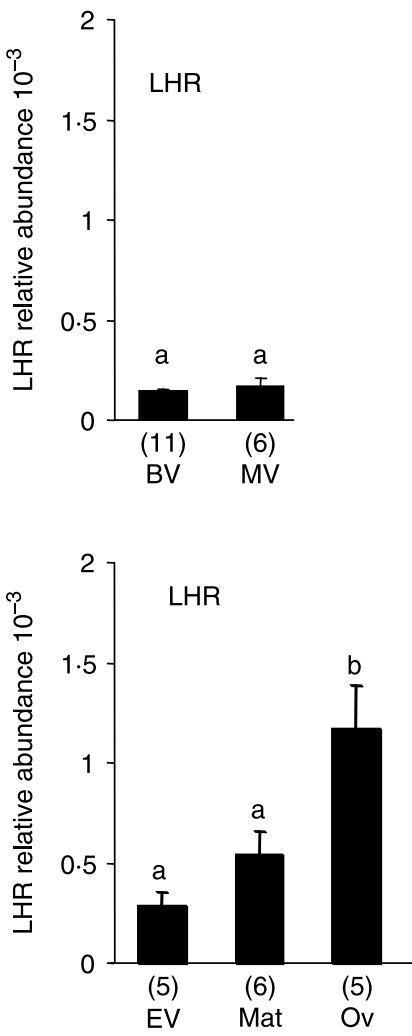
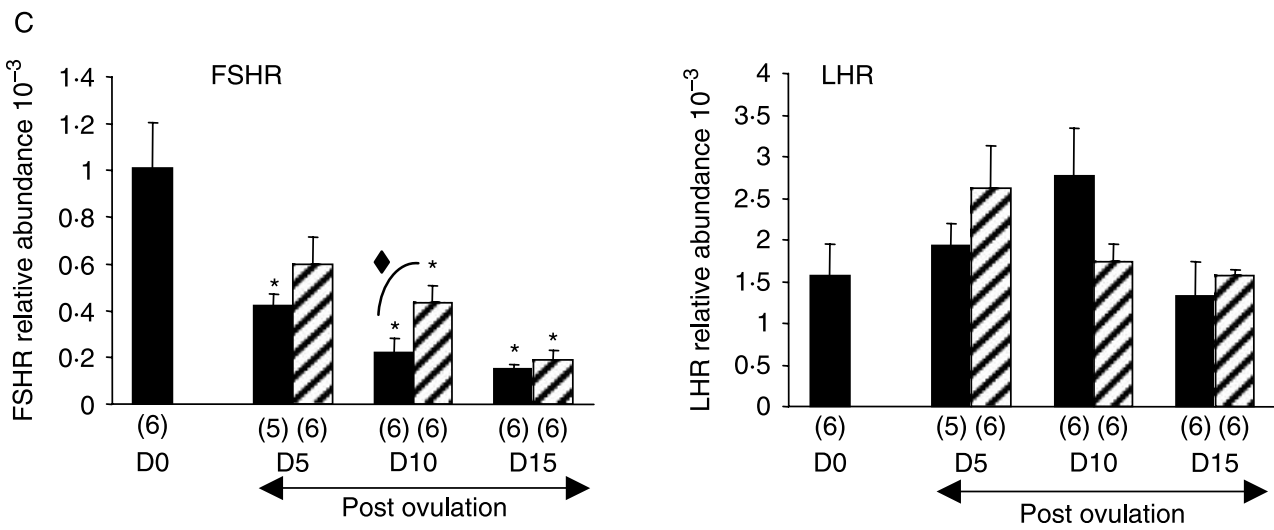

Figure 7 Expression profiles offemale rainbow trout FSHR and LHR transcripts measured by quantitative real-time PCR during the first annual reproductive cycle from early to mid-vitellogenesis (A) and from the end of vitellogenesis to ovulation (B). Each gonadotropin receptor transcript was studied after the ovulation period (C). Expression levels were normalized to $28 \mathrm{~S}$ rRNA. The black bars represent females stripped on the day of ovulation. Hatched bars represent females with eggs retained in the abdominal cavity for 5, 10, or 15 days after ovulation.

* Asterisks represent significant difference $(P<0 \cdot 05)$ compared with D0. The closed diamond symbol indicates significant differences $(P<0 \cdot 05)$ between females with or without eggs retained in the abdominal cavity. Each data point represents the mean \pm S.E.M. of different individual fish. Bars with different letters are significantly different $(P<0 \cdot 05)$. Number of individual fish is indicated between brackets $(n=5-11)$. BV, beginning vitellogenesis; $M V$, mid-vitellogenesis; EV, end vitellogenesis; Mat, maturation; Ov, ovulated females between 0 and 3 days.

weak FSH-induced response was previously reported in amago salmon using purified (Oba et al. 1999b) or recombinant (Ko et al. 2007) heterologous GTH regardless of the direct and indirect intracellular cAMP quantification systems used. Similar observations were also reported in catfish (Kumar et al. 2001b) and zebrafish (Kwok et al. 2005, So et al. 2005).

In our assays, rtLHR was activated not only by rtLH $\left(\mathrm{EC}_{50}=117 \mathrm{ng} / \mathrm{ml}\right)$ but also by $\mathrm{rtFSH}$, albeit at doses at least 
A

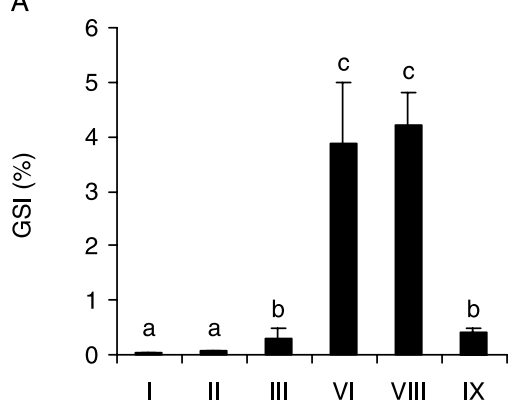

C

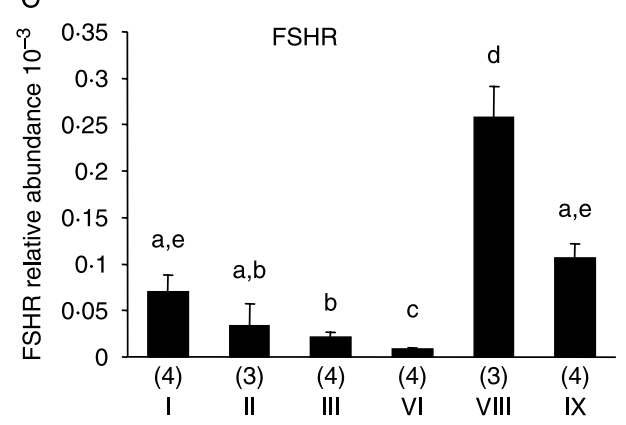

$E$

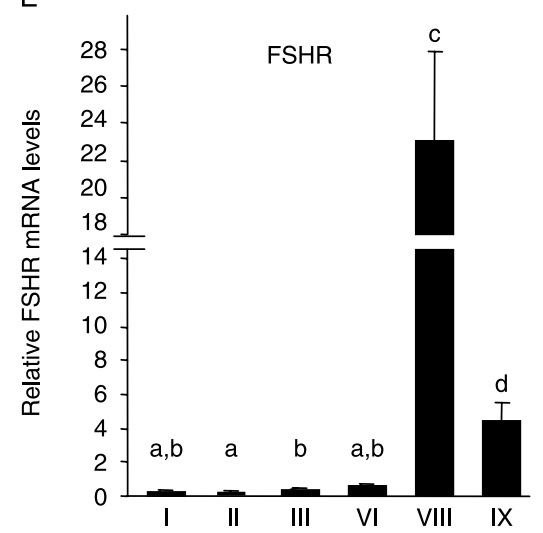

B

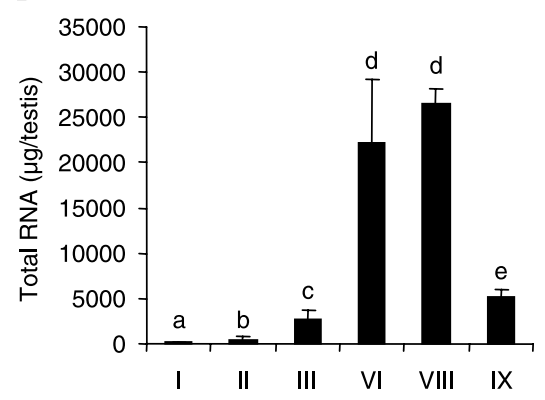

$\mathrm{D}$

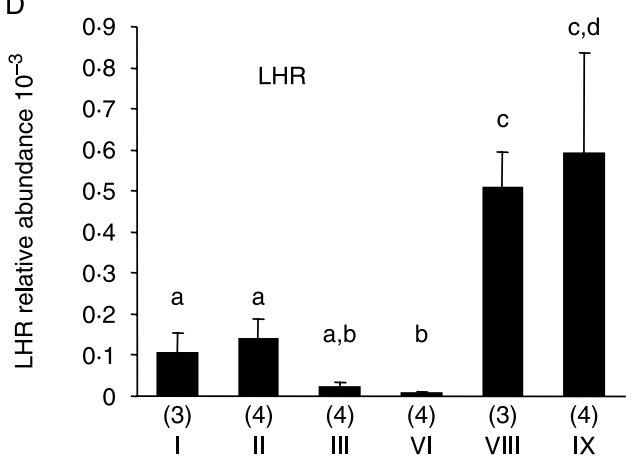

$\mathrm{F}$

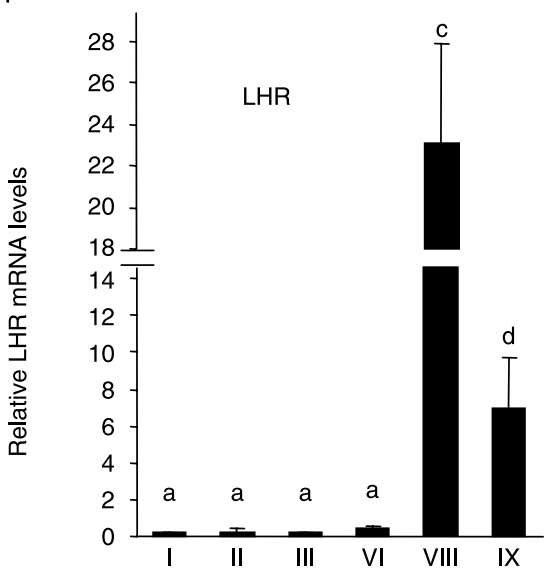

Figure 8 Expression profiles of male rainbow trout FSHR (C and E) and LHR (B and F) transcripts measured by quantitative real-time PCR during the first annual reproductive cycle: from immature (stage $\mathrm{I}$ ) to post-spermiation (stage IX). The gonadosomatic index (A) and calculated total RNA content per testis (B) are presented. Expression data were normalized to $28 \mathrm{~S}$ rRNA (C and D) or the gonadal RNA content ( $E$ and $F$ ) as described previously (Kusakabe et al. 2006). Each data point represents the mean \pm s.E.M. $(n=3-4)$. The number of individual fish is given in parentheses. Bars with different letters are significantly different $(P<0 \cdot 05)$.

five times higher $\left(\mathrm{EC}_{50}=598 \mathrm{ng} / \mathrm{ml}\right)$. In addition, cells expressing rtLHR showed a high maximum response in the presence of $\mathrm{rtLH}(8 \cdot 9$-fold) that was significantly reduced in the presence of $\mathrm{rtFSH}(2 \cdot 9$-fold), independent of the dose used (up to $800 \mathrm{ng} / \mathrm{ml}$ ). However, the activation of the rtLHR by homologous FSH was not observed upon stimulation by the heterologous chinook FSH. Contamination of the purified rtFSH fractions by rtLH may account for such an activation, although no trace of $\mathrm{rtLH}$ was detected by radio immunoassay in the purified rtFSH preparation (Govoroun et al. 1998). Other hypotheses include a weaker affinity of the heterologous hormone for the trout GTH receptors. This hypothesis is supported by the fact that the chinook FSH preparation used in the study specifically activated rtFSHR, but higher doses were required compared with the homologous rtFSH preparation. Unfortunately, we could not test very high concentrations because of limited availability of purified chinook GTHs. 
Interestingly, the functional specificity of the trout GTH receptors is consistent with the reports in amago salmon, showing that, in vitro, a unique high concentration $(5 \mu \mathrm{g} / \mathrm{ml})$ of purified heterologous $\mathrm{LH}$ or $\mathrm{FSH}$ preferentially activates their cognate receptors (Oba et al. 1999a,b). These observations were recently confirmed using recombinant Manchurian trout GTHs (Ko et al. 2007). The prominent selective activation of the salmonid GTH receptors is rather unexpected since previous GTH-binding studies on membrane preparations from pacific salmon gonads demonstrated that FSHR bound both hormones, whereas LHR bound LH with a rather high selectivity (Yan et al. 1992). The difference observed between the results of the binding and activation studies suggests that $\mathrm{LH}$ binding to FSHR would result in a ligand/receptor complex unable to activate the adenylate cyclase in the COS cellular context. In addition, we cannot rule out the hypothesis that $\mathrm{rLH} / \mathrm{FSHR}$ complexes may activate other unknown signaling pathways.

In zebrafish, the functional specificity seems less prominent since recombinant zfFSH specifically stimulated its cognate receptor, whereas recombinant $\mathrm{zfLH}$ efficiently activated both GTH receptors (So et al. 2005). Similarly, in African catfish, recombinant cfFSH specifically stimulated cfFSHR whereas recombinant and purified cfLH were efficient in activating FSHR, although with a potency 10 - to 20-fold lower (Vischer et al. 2003). Our study, together with other studies, indicates that the in vitro selective activation of the fish GTH receptors may differ depending on the fish species and/or order. In trout and amago salmon, FSHR and LHR would be specifically induced by their respective ligands, whereas in African catfish (Siluriforms) and zebrafish (Cypriniforms), which are two phylogenetically closely related species, FSHR would be efficiently activated by both hormones. In Siluriforms and Cypriniforms, but not in Salmoniforms, the $\mathrm{N}$-terminal end of the FSHR exhibits two of four conserved cysteine residues present on a classical pCRR. These residues have been involved in disulfide bond formation and are part of a structural determinant required for efficient $\mathrm{LH}$ binding in mammals (Zhang et al. 1996). Whether these two conserved cysteine residues are involved in catfish and zebrafish FSHR folding and LH signal transduction remains to be investigated.

\section{Expression of the GTH receptor genes in the gonad}

In female trout, rtFSHR gene expression significantly increased at the maturation stage prior to ovulation. Such a FSHR gene expression pattern was also described in the tilapia (Oba et al. 2001) and zebrafish (Kwok et al. 2005). The physiological significance of high FSH levels and FSHR gene expression during oocyte maturation and spawning in salmonids remains puzzling. However, in mammals (Hoak \& Schwartz 1980) and fish (Prat et al. 1996, Tyler et al. 1997), it has been proposed that FSH plays a role in follicle recruitment for the next reproductive cycle. Meanwhile, recombinant $\mathrm{FSH}$ injected into female rats induces not only follicle growth but also ovulation (van Cappellen et al. 1995).
In trout, Bobe et al. (2003) found a positive correlation between the relative abundance of rtFSHR transcript and high follicular maturational competence. The rtLHR gene expression pattern in the ovary showed a progressive increase in LHR transcript abundance from the end of vitellogenesis to ovulation. Such a pattern is similar to that described in zebrafish (Kwok et al. 2005). The higher expression of GTH receptors in maturing and ovulated females is consistent with studies showing higher binding sites (Breton \& Sambroni 1989) and high plasma GTH levels (Breton et al. 1998) in sexually mature females. Altogether, these results agree with the known functions of LH on ovarian steroidogenic activity, oocyte maturation, and spawning (Patino \& Sullivan 2002).

In male trout, FSHR mRNA was detected in early gonadal maturation stages at Sertoli cell proliferation and differentiation (stages I and II). The presence of rtFSHR at the beginning of the cycle reinforces the idea that FSH could mediate Sertoli cell proliferation, as proposed previously in catfish and tilapia (Schulz et al. 2005). In the present study, the relative abundance of rtFSHR mRNA appeared to decrease progressively as the proportion of germ cells increased in the gonad (stages III and VI). A similar pattern was observed for the LHR transcript. Are these apparent variations reflecting a down-regulation of the GTH receptor genes? Gonadal FSHR mRNA expression was found to decrease after exogenous androgen treatment in immature catfish (Schulz et al. 2003). We do not exclude that a similar hormonal regulation may occur in trout, since the decrease in relative abundance of rtFSHR transcript also coincides with a slow increase in plasma testosterone levels described previously in our trout strain between stages I and VI (Gomez 1998). However, if we assume that the GTH receptors are mainly expressed in somatic cells, the decrease in the relative abundance of the receptor transcripts would most likely be due to a 'dilution' effect. In fact, when the receptor mRNA abundance is expressed as total amount per testis, no significant decrease in rtLHR or rtFSHR abundance could be detected between stages III and VI of gonadal development. In a recent study, in which the transcript content was expressed per gonad, the amount of FSHR messengers was even found to increase coincidently with gonadal growth and with the increase in germ cell differentiation (meiosis and spermiogenesis; Kusakabe et al. 2006). In that study, LHR gene expression also progressively increased as spermatogenesis progressed and was correlated with plasma LH levels. Further studies will be required to determine whether changes in the relative abundance of GTH receptor mRNA only result from changes in the proportion of expressing cells or whether they occur as a result of specific regulations in GTH target cells. Unfortunately, our attempt to locate and quantify trout GTH receptor transcripts using radioactive riboprobes on histological sections failed, most likely because of the low expression levels (Ricordel et al., personal communication).

The expression pattern of trout GTH receptor genes shows a large increase in both receptor transcripts in stage VIII, regardless of the normalization procedure used. This increase 
is consistent with studies showing higher LH-binding sites, higher sensitivity to LH in terms of steroid production output (Le Gac \& Loir 1988, Planas \& Swanson 1995), and high plasma GTH levels (Gomez et al. 1999) in prespawning or spawning males. The dramatic increase of rtLHR in stage VIII is also consistent with the fact that, using in vitro ligand autoradiography, LH binding could only be detected in spermiating salmon testis (Miwa et al. 1994).

To conclude, the present study describes the presence of two distinct GTH receptors in rainbow trout showing similarities with those of higher vertebrates, but also differences in terms of their structural determinants (FSHR). The gonadal expression pattern of the GTH receptor genes suggests that FSHR may play an important role in regulating gonadal functions in spawning trout, in addition to the LHR pathway. In vitro functional studies demonstrate that rtLH and rtFSH preferentially activate their cognate receptor.

\section{Acknowledgements}

The authors are indebted to Dr Govoroun for providing with the purified rainbow trout and chinook salmon gonadotropins. The testis cDNA library was kindly provided by $\operatorname{Dr} Y$ Guiguen. The authors are grateful to R Salesse and J J Rémy for their helpful advice at the beginning of the study. We thank Miranda Maybank for improving the English language of the manuscript. This work was supported in part by grants from INRA-IFREMER (grant 93/5 570 086) and the European Union (Q5RS-2002-01801). The authors declare that there is no conflict of interest that would prejudice the impartiality of this scientific work.

\section{References}

Basu D \& Bhattacharya S 2002 Purification of two types of gonadotropin receptors from carp ovarian follicles: overlapping recognition by two different ligands. General and Comparative Endocrinology 129 152-162.

Billard R \& Escaffre AM 1975 Identification des stades de la spermatogenese de la truite fario d'apres la morphologie des gonades et la spermiation. Bulletin Français de Pisciculture 256 111-118.

Bobe J, Maugars G, Nguyen T, Rime H \& Jalabert B 2003 Rainbow trout follicular maturational competence acquisition is associated with an increased expression of follicle stimulating hormone receptor and insulinlike growth factor 2 messenger RNAs. Molecular Reproduction and Development 66 46-53.

Bogerd J, Blomenrohr M, Andersson E, van der Putten HH, Tensen CP, Vischer HF, Granneman JC, Janssen-Dommerholt C, Goos HJ \& Schulz RW 2001 Discrepancy between molecular structure and ligand selectivity of a testicular follicle-stimulating hormone receptor of the African catfish (Clarias gariepinus). Biology of Reproduction 64 1633-1643.

Breton B \& Sambroni E 1989 Evolution du nombre des récepteurs gonadotropes ovariens au cours du cycle reproducteur annuel chez la truite fario Salmon trutta L. Comptes Rendus de l'Academie des Sciences. Série III, Sciences de La Vie 308 495-500.

Breton B, Le Gac F \& Sambroni E 1986 Gonadotropin hormone (GtH) receptors in the ovary of the brown trout Salmo trutta L. in vitro studies. General and Comparative Endocrinology 64 163-171.
Breton B, Govoroun M \& Mikolajczyk T 1998 GTHI, GTH II, secretion profiles during the reproductive cycle in female rainbow trout: relationship with pituitary responsiveness to GnRH-A stimulation. General and Comparative Endocrinology 111 38-50.

Campbell B, Dickey J, Beckman B, Young G, Pierce A, Fukada H \& Swanson P 2006 Previtellogenic oocyte growth in salmon: relationships among body growth, plasma insulin-like growth factor-1, estradiol-17beta, folliclestimulating hormone and expression of ovarian genes for insulin-like growth factors, steroidogenic-acute regulatory protein and receptors for gonadotropins, growth hormone, and somatolactin. Biology of Reproduction 75 34-44. van Cappellen WA, Meijs-Roelofs HM, Kramer P, van Leeuwen EC, de Leeuw R \& de Jong FH 1995 Recombinant FSH(Org32489), induces follicle growth and ovulation in the adult cyclic rat. Journal of Endocrinology 144 39-47.

Fredriksson R, Lagerstrom MC, Lundin LG \& Schioth HB 2003 The G-protein-coupled receptors in the human genome form five main families. Phylogenetic analysis, paralogon groups, and fingerprints. Molecular Pharmacology 63 1256-1272.

Gabe M 1968 Techniques Histologiques., Paris: Masson \& Cie p 1113.

Le Gac F \& Loir M 1988 Control of testis function in fish: in vitro studies of gonadotropic regulation in the trout (Salmo gairdneri). Reproduction, Nutrition, Development 28 1031-1046.

Le Gac F, Breton B \& Bougoussa M 1988 Gonadotropic hormone (GtH) receptors in the testis of the trout Salmo gairdneri: in vitro studies. Fish Physiology and Biochemistry 5 209-217.

Garczynski MA \& Goetz FW 1997 Molecular characterization of a ribonucleic acid transcript that is highly up-regulated at the time of ovulation in the brook trout (Salvelinus fontinalis) ovary. Biology of Reproduction 57 856-864.

Gomez JM. Relations entre croissance somatique et reproduction chez la truite arc-en-ciel (Oncorhynchus mykiss): aspects morphologiques et endocriniens au cours de la gamétogenèse. Rennes University. 1998 (Ref. type: Thesis/Dissertation).

Gomez JM, Weil C, Ollitrault M, Le Bail PY \& Le Gac F 1999 Growth hormone $(\mathrm{GH})$ and gonadotropin subunit gene expression and pituitary and plasma changes during spermatogenesis and oogenesis in rainbow trout (Oncorhynchus mykiss). General and Comparative Endocrinology 113 413-428.

Govoroun MS, Huet JC, Pernollet JC \& Breton B 1997 Use of immobilized metal ion affinity chromatography and dye-ligand chromatography for the separation and purification of rainbow trout pituitary gonadotropins, GTH I and GTH II. Journal of Chromatography. B 698 35-46.

Govoroun M, Chyb J \& Breton B 1998 Immunological cross-reactivity between rainbow trout GTH I and GTH II and their alpha and beta subunits: application to the development of specific radioimmunoassays. General and Comparative Endocrinology 111 28-37.

Hoak DC \& Schwartz NB 1980 Blockade of recruitment of ovarian follicles by suppression of the secondary surge of follicle-stimulating hormone with porcine follicular fluid. PNAS 77 4953-4956.

Jalabert B 1976 In vitro oocyte maturation and ovulation in rainbow trout (Salmo gairdnery), northern pike (Esox lucius), and goldfish (Carassius auratus). Journal of the Fisheries Research Board of Canada 33 974-988.

Kajava AV 1998 Structural diversity of leucine-rich repeat proteins. Journal of Molecular Biology 277 519-527.

Kajava AV, Vassart G \& Wodak SJ 1995 Modeling of the three-dimensional structure of proteins with the typical leucine-rich repeats. Structure $\mathbf{3}$ 867-877.

Kanamori A, Kagawa H \& Nagahama Y 1987 Gonadotropin receptors in the postovulatory ovary of amago salmon (Oncorhynchus rhodurus). General and Comparative Endocrinology 66 210-217.

Ko H, Park W, Kim DJ, Kobayashi M \& Sohn YC 2007 Biological activities of recombinant Manchurian trout FSH and LH: their receptor specificity, steroidogenic and vitellogenic potencies. Journal of Molecular Endocrinology 38 99-111.

Kumar RS, Ijiri S \& Trant JM 2001a Molecular biology of channel catfish gonadotropin receptors: 1 cloning of a functional luteinizing hormone receptor and preovulatory induction of gene expression. Biology of Reproduction 64 1010-1018. 
Kumar RS, Ijiri S \& Trant JM $2001 b$ Molecular biology of the channel catfish gonadotropin receptors: 2 complementary DNA cloning, functional expression, and seasonal gene expression of the follicle-stimulating hormone receptor. Biology of Reproduction 65 710-717.

Kusakabe M, Nakamura I, Evans J, Swanson P \& Young G 2006 Changes in mRNAs encoding steroidogenic acute regulatory protein, steroidogenic enzymes and receptors for gonadotropins during spermatogenesis in rainbow trout testes. Journal of Endocrinology 189 541-554.

Kwok HF, So WK, Wang Y \& Ge W 2005 Zebrafish gonadotropins and their receptors: I cloning and characterization of zebrafish folliclestimulating hormone and luteinizing hormone receptors - evidence for their distinct functions in follicle development. Biology of Reproduction $\mathbf{7 2}$ 1370-1381

Laan M, Richmond H, He C \& Campbell RK 2002 Zebrafish as a model for vertebrate reproduction: characterization of the first functional zebrafish (Danio rerio) gonadotropin receptor. General and Comparative Endocrinology 125 349-364.

Livak KJ \& Schmittgen TD 2001 Analysis of relative gene expression data using real-time quantitative PCR and the $2-\Delta \Delta$ CT method. Methods 25 402-408.

Loir M 1994 In vitro approach to the control of spermatogonia proliferation in the trout. Molecular and Cellular Endocrinology 102 141-150.

Loir M 1999 Spermatogonia of rainbow trout: II in vitro study of the influence of pituitary hormones, growth factors and steroids on mitotic activity. Molecular Reproduction and Development 53 434-442.

Maugars G \& Schmitz M 2006 Molecular cloning and characterization of FSH and LH receptors in Atlantic salmon (Salmo salar $\mathrm{L}$ ). General and Comparative Endocrinology 149 108-117.

Miwa S, Yan L \& Swanson P 1994 Localization of two gonadotropin receptors in the salmon gonad by in vitro ligand autoradiography. Biology of Reproduction 50 629-642.

Oba Y, Hirai T, Yoshiura Y, Yoshikuni M, Kawauchi H \& Nagahama Y 1999a Cloning, functional characterization, and expression of a gonadotropin receptor cDNA in the ovary and testis of amago salmon (Oncorhynchus rhodurus). Biochemical and Biophysical Research Communications 263 584-590.

Oba Y, Hirai T, Yoshiura Y, Yoshikuni M, Kawauchi H \& Nagahama Y $1999 b$ The duality of fish gonadotropin receptors: cloning and functional characterization of a second gonadotropin receptor cDNA expressed in the ovary and testis of amago salmon (Oncorhynchus rhodurus). Biochemical and Biophysical Research Communications 265 366-371.

Oba Y, Hirai T, Yoshiura Y, Kobayashi T \& Nagahama Y 2001 Fish gonadotropin and thyrotropin receptors: the evolution of glycoprotein hormone receptors in vertebrates. Comparative Biochemistry and Physiology. Part B, Biochemistry and Molecular Biology 129 441-448.

Patino R \& Sullivan CV 2002 Ovarian follicle growth, maturation, and ovulation in teleost fish. Fish Physiology and Biochemistry 26 57-70.

Planas JV \& Swanson P 1995 Maturation-associated changes in the response of the salmon testis to the steroidogenic actions of gonadotropins (GTH I and GTH II) in vitro. Biology of Reproduction 52 697-704.

Planas JV, Athos J, Goetz FW \& Swanson P 2000 Regulation of ovarian steroidogenesis in vitro by follicle-stimulating hormone and luteinizing hormone during sexual maturation in Salmonid fish. Biology of Reproduction 62 1262-1269.

Prat F, Sumpter JP \& Tyler CR 1996 Validation of radioimmunoassays for two salmon gonadotropins (GTH I and GTH II) and their plasma concentrations throughout the reproductive cycle in male and female rainbow trout (Oncorhynchus mykiss). Biology of Reproduction 54 1375-1382.

Quesnel H \& Breton B 1993 Solubilization and purification of the gonadotropin (GTH II) receptor from rainbow trout (Oncorhynchus mykiss) ovaries. General and Comparative Endocrinology 91 272-280.

Remacle C 1976 The action of hormones on the male germinal cells of Carassius auratus L. in organ culture. General and Comparative Endocrinology 29 480-491.

Salmon C, Kagawa H, Adachi S, Nagahama Y \& Fontaine YA 1984 Demonstration of specific gonadotropin binding sites of chum salmon
(Oncorhynchus keta) in membrane preparations of granulosa cells from the ovary of amago salmon (Oncorhynchus rhodurus). Comptes Rendus de l'Acad?mie des Sciences. Série III, Sciences de La Vie 298 337-340.

Sambroni E, Gutieres S, Cauty C, Guiguen Y, Breton B \& Lareyre JJ 2001 Type II iodothyronine deiodinase is preferentially expressed in rainbow trout (Oncorhynchus mykiss) liver and gonads. Molecular Reproduction and Development 60 338-350.

Schulz R, Dijk W \& Bogerd J 2003 Sertoli cell proliferation and FSH signalling in African catfish, Clarias gariepinus. Fish Physiology and Biochemistry 28223.

Schulz RW, Menting S, Bogerd J, Franca LR, Vilela DAR \& Godinho HP 2005 Sertoli cell proliferation in the adult testis - evidence from two fish species belonging to different orders. Biology of Reproduction $\mathbf{7 3}$ 891-898.

Sekine S, Saito A, Itoh H, Kawauchi H \& Itoh S 1989 Molecular cloning and sequence analysis of chum salmon gonadotropin cDNAs. PNAS $\mathbf{8 6}$ 8645-8649.

So WK, Kwok HF \& Ge W 2005 Zebrafish gonadotropins and their receptors: II cloning and characterization of zebrafish follicle-stimulating hormone and luteinizing hormone subunits - their spatial-temporal expression patterns and receptor specificity. Biology of Reproduction $\mathbf{7 2}$ 1382-1396.

Sohn YC, Yoshiura Y, Kobayashi M \& Aida K 1999 Seasonal changes in mRNA levels of gonadotropin and thyrotropin subunits in the goldfish, Carassius auratus. General and Comparative Endocrinology 113 436-444.

Suzuki K, Kawauchi H \& Nagahama Y 1988 Isolation and characterization of two distinct gonadotropins from chum salmon pituitary glands. General and Comparative Endocrinology $\mathbf{7 1}$ 292-301.

Swanson P, Bernard M, Nozaki M, Suzuki K, Kawauchi H \& Dickoff WW 1989 Gonadotropins I and II in juvenile coho salmon. Fish Physiology and Biochemistry 7 169-176.

Swanson P, Suzuki K, Kawauchi H \& Dickhoff WW 1991 Isolation and characterization of two coho salmon gonadotropins, GTH I and GTH II. Biology of Reproduction 44 29-38.

Trinh KY, Wang NC, Hew CL \& Crim LW 1986 Molecular cloning and sequencing of salmon gonadotropin beta subunit. European Journal of Biochemistry 159 619-624.

Tyler CR, Sumpter JP, Kawauchi H \& Swanson P 1991 Involvement of gonadotropin in the uptake of vitellogenin into vitellogenic oocytes of the rainbow trout, Oncorhynchus mykiss. General and Comparative Endocrinology 84 291-299.

Tyler CR, Pottinger TG, Coward K, Prat F, Beresford N \& Maddix S 1997 Salmonid follicle-stimulating hormone (GtH I) mediates vitellogenic development of oocytes in the rainbow trout, Oncorhynchus mykiss. Biology of Reproduction 57 1238-1244.

Vischer HF \& Bogerd J 2003 Cloning and functional characterization of a gonadal luteinizing hormone receptor complementary DNA from the African catfish (Clarias gariepinus). Biology of Reproduction 68 262-271.

Vischer HF, Granneman JC, Linskens MH, Schulz RW \& Bogerd J 2003 Both recombinant African catfish LH and FSH are able to activate the African catfish FSH receptor. Journal of Molecular Endocrinology 31 133-140.

Yan L, Swanson P \& Dickhoff WW 1992 A two-receptor model for salmon gonadotropins (GTH I and GTH II). Biology of Reproduction 47 418-427.

Zhang R, Buczko E \& Dufau ML 1996 Requirement of cysteine residues in exons 1-6 of the extracellular domain of the luteinizing hormone receptor for gonadotropin binding. Journal of Biological Chemistry 271 5755-5760.

Received in final form 2 August 2007

Accepted 15 August 2007

Made available online as an Accepted Preprint 15 August 2007 